\title{
Law and Culture: 'Urf as a Substance of Islam Nusantara as Reflected in Indonesian Religious Court Decisions
}

\author{
JM. Muslimin \\ Graduate School \\ Syarif Hidayatullah State Islamic University, Jakarta - Indonesia \\ jm.muslimineuinjkt.ac.id
}

\begin{abstract}
The aim of this study is to show the continuity of interaction between sharia and local living norms and culture as reflected in the Religious Court Decisions on Islamic Personal Law cases. From the beginning of its formative years, sharia and culture are interrelated closely. The specific terminology of amal ahl al-madinah indicates that not all Islamic norms are derived directly from the scripture. But it is linked to the local practice and living norms, customs, and usage. The research is qualitative, using documents as source of data. The documents are consisting of some Indonesian Religious Court Decisions. The Court Decision (year 2000 onward) of Jember, Binjai, Kudus, Bandung, Watansoppeng, and Jakarta are analyzed. The result of the research shows the legal ideas of interpreting sharia must refer to the living norms embedded in the local wisdom and tradition. By doing such a method of reference, the decision is practical and fulfil the feeling of people justice. Thus, sharia, as indicated in the decisions is "localfiqh".
\end{abstract} fiqh

\section{Keywords- 'Urf; Islam Nusantara; religious court; local}

\section{INTRODUCTION}

Ibn Mandhur sees that the word al-'urf is in the same root of al-ma'rüf meaning something familiar and brings about composure to soul, as the opposite of al-munkar meaning something that is unknown and brings about confusion and uneasiness to soul [1, p. 239]. While Taqiyuddin al-Hambali maintains that al- 'urf is every thing known or done by many people and does not break the rule al-Hambali [2, p. 447]. Similarly Abdul Wahhab Khallaf says that al- urf is a social concept that is commonly known and performed like many people including utterances, actions or something left, and according to him that al- $u r f$ is the same as tradition [3, p. 85].

Majority of Muslim Scholars maintain that al-urf is a proposition used to contrive Islamic law because it always relates with human rights that does not conflict with the source of Islamic shari'ah (law) [3, p. 88]. The scholars of Shafi'i school of law, for example, use al- 'urf for everything they cannot find any definition in Sharia and in language. The norm that they use as a base by the Shafi'ites is the following expression:
"Everything that Sharia brings with absolutely and there is no definition in Islamic law and language, it is returned to al- "urf."

It can be assumed that the above principle gets its inspiration from the Word of Allah:

"Be a forgiver and order people to do the good deed and turn from the foolish."

Al-Qurtubi confirms that the word al-'urf in the verse above is good customs in the social intercourse and they are received by mind and soul [4, p. 344]. Someone who always uses al-urf in his life, he will promote tolerance and easiness, not difficulty [5, p. 215]. Shatibi will not regard it as al-'urf if there is a difficulty in it [6, p. 220].

"Ibn Mas'ud r.a. says: Something which most Muslims regard good is good in Allah's sight." [7, p. 631].

Muslim scholars accept al-'urf as an argumentation in inventing a law with several conditions, namely: (al-Zuhaily 1418:840-850).

1) Al- 'Urf contains general interest (maqāṣid al-sharī'ah)

2) Al-'Urf has become patterns of conduct and strong norms within the milieu of al- 'urf.

3) Al- 'Urf has been examined as normative solution.

4) Al-'Urf is in accordance with the spirit of stipulation found in the Qur'an and al- Hadith

5) Al-'Urf is not contradictive with the principle and coherence of law.

6) Al-'Urf is in accordance with traditions and honor human kind and does not humiliate it and it is responsive, not retaliatory.

The usage of al-'urf as a proposition needs to be supported by another proposition. Because it is not a proposition which can stand itself. In the sense that al-'urf must need a support of a definitive argumentation (qath'i), while a nash (stipulation in the Qur'an and Traditions) does not need any support. For example, the Messenger of Allah ever gave an advice on the matter of expense given to Hindun. 
"Aisyah relates that Hindun, the daughter of Utbah, Abu Sufyan's wife met Rasulullah saying: Oh Rasulullah, indeed Abu Sufyan is a stingy man. He does not give me enough maintenance for me and my children other than what I take a part from his wealth without his knowledge. Do I make sin for my undertaking? The Messenger of Allah said, 'Take some of his wealth with a good way and adequate for you and for your children." (Narated by Bukhari)

In the above hadith, the Messenger of Allah gave a solution to Hindun, Abu Sufyan's wife to deal with the stingy husband. The example of this proposition is al-'urf example that is based on the nas (text of the Qur'an or Sunnah) in which the decision of the proper money should be given to one's wife must fulfill the wife's need while considering the husband's capacity and also pays attention to al-'urf that applies in a society when the marriage takes place. From the above conclusion, a certainty can be drawn that $a l$ - 'urf is used as proposition to draw a rule as long as it fulfills a number of specific conditions [8].

Ali Jum'ah asserts that the importance of al-'urf in the formation of Islamic law, one of them is seen in the following principle. [9, p. 336].

"Tradition can be made as law."

"The stipulation using al- 'urf like stipulation using the Nas (Qur'an and al-Hadith)

On the actual practice in the society, the principle of fiqh (Islamic jurisprudence) helps greatly decision makers to handle a variety of problems that happen in the social order, whether that directly deals with maintenance, dowry, and salary for nursing. Therefore, the critical application which contains in the norms of Fiqh (Islamic jurisprudence) helps considerably Muslim community in handling legal cases which prevail in the Muslim society all the time. It is this norm that causes the jurists take analytical and proactive approach in tackling various problems faced by Muslim Community. This happens because this Islamic jurisprudence norm was born as a discipline on the intention to inspire it from taqlïd (unquestioning acceptance of traditional religious interpretation) and the spirit of ijtihād (independent judgment in a legal or theological question) $[6$, p. 9]. as it is indicated in this study.

\section{METHOD}

This research is a document study focusing on the Indonesian Religious Court's decision 2000-onward. In line with Slavin [10, p. 122], Rossman and Ralls [11, p. 26], argued that during the research, a qualitative researcher is involved in diverse and multifaceted levels, implying that the result of the study concluded is basically interpretive. The researcher interprets what he learns as he goes along. Data are classified and filtered through the researcher's own of his lens and worldview. The analysis includes: 1) descriptive analysis that includes gathering the documents carefully, classifying and analysing the collected one, 2) making linkage and matching the meaning and interpretation. The documents are analysed in order to catch the inner messages which are compatible to the main topic and the goals of research.

\section{RESULT AND DISCUSSION}

\section{A. Historicity of 'Urf and its Institutionalization}

Islamic law as a science cannot be discharged totally from its historicity [12, p. 499]. Because if it is seen from historical usage of 'urf it can be understood that the application of Islamic law is always driven and based on the principle to consider the familiar conduct of society and considering tolerance and facility. So it is this process that is introduced by the Muslims scholars as al-'adah almuhakkamah as has been explained before. Muhammad Sidqi Ahmad al-Burnu conceptualized it on the order of Islamic jurisprudence to be a new concept as follows;

"Actually, tradition is made as a law which is not, butto decide Islamic law”[13, p. 68].

Ibn al-Farra concludes that $a l$-'urf is an unwritten law. It grows and develops following community's tradition development with which they go along. It intends to assure that society's life is in peace, prosperous and no much conflict and useless division. So the existence of 'urf in a society is a result of mutual agreement which becomes a basis of a common interest. The 'urf, therefore, becomes one of the legal source of Islamic laws, arranging the living social system in that region.

The history of the Islamic law formation constitutes Prophet Muhammad's legitimacy to the companions' sayings and actions when he saw or knew the event from someone else by silent attitude or another way. Abdul Wahab Khallaf mentions that the event where Islamic law was formed is called sunnah taqririyyah (stipulated tradition) or its argumentation which acts as a legitimacy to the Arab community's 'urf at that time to be a part of Islamic law [3, p. 36].

On this matter, the Prophet did not ever prohibit 'urf șahīh (good tradition), above all it brings good influence to the community's welfare. While on al- 'urf al-fāsid (bad tradition) the Messenger of Allah would remind them to the possibility that it would result in some damages and disturb community speace. So, Islamic law should not only be executed, but it experiences transformation so that it keeps moving along with the development of condition and situation.

Pre-Islamic Arabian laws were traditional, tribal and primitive. The Arabs arranged their social life with moral values of the Arab community that became a set of conservative and static laws and constituted legal legacy from generation to generation. The presence of Islam which did not purge whole Arab tribal traditions enabled them to be more confident in the new religion with open hearted acceptance because the faith that Islam introduced to them was not different from the tradition of Arab ancestors. Islam, instead, accommodates some conservative elements hold strongly by the Arabs from generation to generation [14, p. 72]. 
Wahbah Zuhaily asserts that if he finds in the hadith about a law and a case he is examining. He uses 'amaliyyah hadīth or taqrīryyah as a proposition or source of law. However, if he does not find in both sources, he does not find a legal certainty from the case that he is examining. Wahbah Zuhaily then pays attention to scholars' opinion by observing the hadith which is made as proposition by those scholars between its validity and weakness by way of extraction and verification in order that the validity and frailty of those hadiths can be known so that one can choose the opinion based on valid hadith [15, p. 165].

In Abu Hanifah's time, the influence of al-urf appeared clearly when he included traditions in the principle of his istihsān. He made his own opinion by utilizing a variety of social traditions and customs as a secondary legal source as long as his decision did not conflict with the nas and maqāssid al-shari'ah. Similarly, Imam Malik supported the inhabitants of Medina as part of his legal theory, and Imam Shafi'i who gave fatwa (formal legal opinion) on the condition of a society at that time, like old opinion and new one that happened in various countries such as Irak and Hijaz [16, p. 254].

Islamic expansion kept stretching with the aim to improve the social system in order to become more prestigious and prosperous in accordance with the goal of the Islamic law as a guide to perform the religious duty. Its expansion was through peaceful penetration, tolerant, and constructing the existing traditions. So, that Islamic teachings easily entered Indonesia where Indonesia people at the beginning accepted Hindu culture blindly, then Islam brought about changes towards a community that applied Islamic law as a guide for social interaction [17, pp. 75-90].

\section{B. Indonesian Islam and 'Urf: Acculturation and Accommodation}

'Urf struggle in overcoming the changes in cultural and religious values was not a new thing in handling the problems of the daily routine of the community, for instance. In Indonesia. Indonesia owns the important cultural legacy in defending culture elements from generation to generation. As we know that the revelation in the form of al-Qur'an and alHadith is also a result a result of dialectics with the Arab through their language and culture, so that starting from this reality it is very important to make adjustment with the Islamic law.

There were several Islamic kingdoms in Indonesia like Pajang, Mataram and Aceh sultanate led by Iskandar Muda (1637-1636) that owned their own sources of law taken from Islamic law. Besides, some figures provided constructive offers and paradigmatic Fiqh formal according to Indonesian style. For example, Hasbi al-Shidqi early Muslim scholar who made Indonesian fiqh, then Hazairin who thought of Indonesian madzhab (Indonesian school of law) or Shafi'i plus madzhab with the project among others was a plan of national inheritance law [18, p. 190].

This kind of effort did not stop right there, K.H. Sahal Mahfudz had an idea of a norm that was based on the legal fiqh of the Indonesian society. This was performed by him as an idea of social figh which was aimed to give an alternative answer to reconcile between the revelation authenticity and social reality in Indonesia [18, p. 190]. Besides, K.H. Abdurrahman Wahid (Gus Dur) also offered an idea of adjusting Islam to indigenous Indonesian character and contextualization of figh. All those ideas are important in the effort to apply religious norms on the social reality through a dynamic purification in the tajdìd (reformation) towards the realization of new understanding in applying Islamic law.

\section{Cases and Court Decisions}

Some cases and court decisions are worthy to be discussed. The decisions indicate clearly that the judges in Religious Courts consider al-'urf as one of the main arguments in resolving the cases [19] [20] [21] [22] [23] [24]. Moreover, they have expanded their interpretation. They consider the global goodness and habit to be included as 'urf. The decisions are summarized from three categories of cases: dispute on marital property, nushīz as the cause of divorce and child custodian [25, pp. 45-46] [26, pp. 101168].

Disputes on marital property cases are from Jember East Java (Putusan Nomor 1933/P.dt.G/2007/PA.Jr), Binjai North Sumatera (Putusan Nomor 204/P.dt.G/ 2014/PA.Bji), Watansoppeng South Sulawesi (Putusan Nomor 0034/P.dt.G/2011/PA. WSP) and Kudus Central Java (Putusan Nomor 0962/P.dt.G/2011/PA/Kds). Traditionally, those districts were known as santri (pious Muslim) cities. The decisions on nushüz which cause divorces are taken from South Jakarta from 2014 to 2015. Decisions on child custodian are from the Supreme Court (Mahkamah Agung) number 210K/ AG/1996, 349K/AG/2006, 110K/AG/2007.

None of those collected decisions tend to neglect al-'urf as living tradition and source of law. On the contrary, al- 'urf is not only derived from local and existing traditional values but also from the living international civil tradition and global wisdom. Therefore it can be stated that like literary works, the embodied and referred al- urf contains mimetic element (global wisdom and human tradition), objective points (legal text and the case), pragmatic essence (tradition of the involved parties in the cases), and expressive wording (the textuality of the law and formal legal position of 'urf itself).

In the cases of child custodian, no decision ignores the right of women to have property share. Moreover, the women is entitled to equal sharing (fifty-fifty). In the cases of $n u s h \bar{u} z$ as the cause of divorce, the judges clearly have the conclusion that the divorce is not merely due to the absence of woman's obedience to her spouse, but also due to the absence of man's obedience to his spouse. Both have equal rights and duties.

And in the case of child custodian, the judges state that it is not only the right and duties of women but also the right and duties of man. Man is entitled to bring up the children and so is woman. 


\section{CONCLUSION}

To summarize the research, then writer consider al-urf (with extended definition) as the main reference of judging. The decisions clearly state and emphasize the equal right between man and woman.

Thus, in practical norms sharia had found its definition in the Indonesian Religious Courts; it has cultural legal substance. It goes hand in hand with local as well as international values and wisdom. The globalized world and values in the decisions are united. But the local and Islamic values are embedded. This unique phenomenon indicates that Islam Nusantara is made by the real and empirical practice of Indonesian people.

Further study on the decisions from interdisciplinary approach is necessary. It can be completed by field-research in order to see the impact of decisions in the daily life of Indonesian Muslims.

\section{REFERENCES}

[1] Ibn Manzhur, Lisān al- 'Arab. Beirut: Dar al-Shadir, 1414.

[2] T. al-Hambali, Sharh al-Kawkab al-Munir. Kairo: Maktabah Ubaik, 1997.

[3] A. W. Khallāf, Ilmu Ușūl al-Fiqh wa al-Khulāṣah al-Tārīkh al-Tasyrì'. Mesir: Dar al- Madani, 1988.

[4] Al-Qurthubi, al-Jāmi' li ahkām al-Qur'ān. Kairo: Dar al-Kutub alMishriyyah, 1964.

[5] W. al-Zuhaily, Tafsīr Munīr fi al-Aqidah wa al-Shari'ah wa al-Manhaj. Damaskus: Dar al- Fikr, 1418.

[6] Al-Shātibi, Muwafaqāt. Beirut: Dar Ibn Affan, 1997.

[7] M. al-Hayyi, al-Ta'liq al-Munajjad 'alā Muwattha' Muhammad. Damaskus: Dar al- Qalam, 2005.

[8] M. al-Naisābury, al-Naisābury, Muslim. Sahīh Muslim. Juz 3, 1338. Beirut: , t.t: Dar Ihya al-Turats al-'Arabi, 1338.

[9] A. J. M. A. Wahhāb, Al-Madkhal ilā Dirāsāt al-Madhhabi alFiqhiyyah. Kairo: Dar al-Salam, 2001.

[10] R. E. Slavin, Educational Research in an age of Accontability. Boston: Pearson Education, Inc, 2007.

[11] G. B. Rossman, Rallis, and Sharon F, Learning in the Feild; An Introduction to Qualitative Research. Thousand Oaks: Sage Publications, 1998.

[12] I. Shaukāni, "Hakikat Hukum Islam: Antara Divine Law dan Man Made Law," J. Ulumuddin Vol 6 No2 April 2009, vol. 6, No.2, April 2009., no. 2, Apr. 2009.

[13] al-Burnu and Muhammad Sidqi Ahmad, al-Wajīz 'iddah Qawā'id alFiqh al-Khulliyyah. Beirut: Dar al-Fikr.

[14] A. al-Jāziri, al-Jāziri, Abdurrahman. al-Fiqh 'alā almadzāhib al-Arba'ah. Beirut: Dar al-Kutub al- Alamiyyah, tth.

[15] Firdaus Shuhadak and Badrun, "Pemikiran Wahbah Zuhaily tentang Ahkām al-Usrah," J. Shari'ah Dan Huk., vol. 4, no. 2, Desember 2012.

[16] Abu Yazid, "Evolusi Shari'ah dan Wacana Fiqh," Islamica, vol. 4, no. 2, Agustus 2010.

[17] N. Bahruddin, 'Urf dalam Putusan Pengadilan Agama. Jakarta: Cinta Buku Media, 2017.

[18] Muhammad Mukri, "Dinamika Pemikiran Fikih Madzhab Indonesia Perspektif Sejarah Sosial,” Anal. J., vol. 11, no. 2, Feb. 2011.

[19] L. M. Friedman, The Legal System: A Social Science Perspective. New York: Russel Sage Foundation, 1975.

[20] W Friedman, Friedman,W. Legal Theory. London: Stevens and SonsLtd., 1953. London: Stevens and SonsLtd, 1953.

[21] H. L. A. Hart, The Concept of Law. Oxford: Clarendon Press Oxford Univ, Press, 1972. Oxford: Clarendon Press Oxford Univ, Press, 1972.

[22] H. Hanafi, Hermeneutic, Liberation and Revolution. Cairo: Dar Kebaa Bookshop, 2003.

[23] N. M. Cormick, Legal Reasoning and Legal Theory. Oxford: Clarendon Press, 1978.

[24] I. McLeod, Legal Method. London: Macmillan PressLtd, 1996.
[25] Nurul Hikmah, Penerapan Nușuz di Pengadilan Agama Jakarta Selatan, Analisis Putusan Perceraian Tahun 2014-2015. Jakarta: Cinta Buku Media, 2017.

[26] N. E. Putri, Hak Hadhanah pada Ayah: Analisis Yuriprudensi Mahkamah Agung. Jakarta: Sakata Press, 2017. 